\title{
KINETICS OF MASS LOSS OF ARABICA COFFEE DURING ROASTING PROCESS
}

Doi:http://dx.doi.org/10.1590/1809-4430-Eng.Agric.v36n2p 300-308/2016

\section{GUILLERMO A. VARGAS-ELÍAS ${ }^{1}$, PAULO C. CORRÊA ${ }^{2}$, NATÁlIA R. DE SOUZA ${ }^{3}$, FERNANDA M. BAPTESTINI ${ }^{4}$, EVANDRO DE C. MELO ${ }^{5}$}

\begin{abstract}
Roasting is one of the most complex coffee processing steps due to simultaneous transfers of heat and mass. During this process, beans lose mass because of fast physical and chemical changes that will set color and flavor of the commercial coffee beverage. Therefore, we aimed at assessing the kinetics of mass loss in commercially roasted coffee beans according to heating throughout the processing. For that, we used samples of 350-g Arabica coffee processed grains with water content of $0.1217 \mathrm{~kg} \mathrm{~kg}^{-1}$, in addition to a continuous roaster with firing gas. The roaster had initial temperatures of $285,325,345$ and $380{ }^{\circ} \mathrm{C}$, decreasing during the process up to $255,285,305$ and $335^{\circ} \mathrm{C}$ respectively. Mass loss was calculated by the difference between grain weight before and after roasting. We observed a linear variation directly dependent on roaster temperature. For each temperature during the process was obtained a constant mass loss rate, which was reported by the Arrhenius model with $\mathrm{r}^{2}$ above 0.98 . In a roaster in non-isothermal conditions, the required activation energy to start the mass loss in a commercial coffee roasting index was $52.27 \mathrm{~kJ} \mathrm{~mol}^{-1}$.
\end{abstract}

KEYWORDS: Coffea arabica, mass decrease, roasting degree, roasting temperature, nonisothermal roasting

\section{CINÉTICA DA PERDA DE MASSA DO CAFÉ ARÁBICA DURANTE A TORRAÇÃO}

RESUMO: A torrefação é uma das etapas mais complexa do processamento do café devido à transferência simultânea de calor e massa, em que os grãos perdem massa devido à rapidez das mudanças físicas e químicas, necessárias para produzir a cor e o aroma do café comercial. Assim, objetivou-se com este trabalho determinar a cinética da perda de massa dos grãos de café torrados comercialmente em função da temperatura do processo. Foram usadas amostras de $350 \mathrm{~g}$ de grãos beneficiados de café arábica com teor de água de $0,1217 \mathrm{~kg}_{\mathrm{a}} \mathrm{kg}^{-1}$. Usou-se um torrador com queima de gás constante e temperaturas iniciais de $285 ; 325 ; 345$ e $380{ }^{\circ} \mathrm{C}$, que diminuíram durante a operação até equilibrar-se em 255; 285; 305 e $335{ }^{\circ} \mathrm{C}$, respectivamente. A perda de massa foi calculada a partir do peso dos grãos antes e depois da torração, sendo observada uma variação linear dependente diretamente da temperatura do torrador. Para cada temperatura do processo, foi obtida uma taxa constante de perda de massa, que foi relacionada pelo modelo de Arrhenius com $\mathrm{r}^{2}$ acima de 0,98. Em condições não isotérmicas do torrador, a energia de ativação necessária para iniciar a perda de massa, em índices de torração comercial do café, foi $52,27 \mathrm{~kJ} \mathrm{~mol}^{-1}$.

PALAVRAS-CHAVE: Café arábica, diminuição da massa, grau de torração, temperatura de torrefação, torra não isotérmica.

\footnotetext{
${ }^{1}$ Eng. A grícola, Doutorando, Departamento de Engenharia Agrícola, Universidade Federal de Viçosa / Viçosa - MG, Fone: (506) 84311259, gvargase@ gmail.com

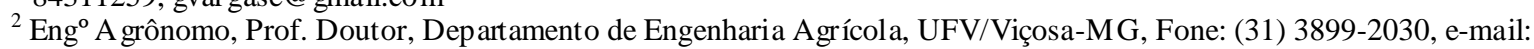
copace@ufv.br

${ }^{3}$ Eng $^{\mathrm{a}}$ de Alimentos, Universidade Federal de Viçosa/Viçosa - MG, natalia.r.souza@ufv.br

${ }^{4}$ Eng a A grícola e Ambiental, Pós-doutoranda em Engenharia Agrícola, Departamento de Engenharia Agrícola, UFV/Viçosa-MG, Fone: (31) 3899-2030, e-mail: fbaptestini@y ahoo.com

${ }^{5}$ Eng $^{\mathrm{o}}$ A grícola, Prof. Doutor, Departamento de Engenharia Agrícola, UFV/Viçosa-MG, Fone: (31) 3899-1873, e-mail: evandro@ufv.br 


\section{INTRODUCTION}

Coffee bean roasting is one of the most critical step in coffee processing, since it controls quality and aggregated commercial value to the product. One example is Germany that is considered the world's largest re-exporter of coffee, importing predominant raw coffee from Brazil, Vietnam and Colombia and re-exporting roasted coffee mainly to the European market (OIC, 2013).

Roasters can be classified by heat transfer and type of operation (continuous or batch) (BONNLÄNDER et al., 2005). The roasters named fluidized bed are operated with heated air under isothermal conditions, in which heat transfer occurs by pure convection. This method can significantly reduce the time of roasting and produce uniformity in coffee color (PERRONE et al., 2010; WANG; LIM, 2013). On the other hand, in the horizontal cylinder roaster, grains undergo different forms of heat transfer like conduction, radiation and natural convection (FABBRI et al., 2011). The first have operating conditions varying from 240 to $270{ }^{\circ} \mathrm{C}$ for approximately 5 minutes; while the last needs temperatures between 400 and $500^{\circ} \mathrm{C}$ for 8 to 20 minutes (BASILE; KIKIC, 2009).

The roasting process consists of a heat treatment in which processed grains undergo high temperatures until reach desirable physical and chemical changes such as color and characteristic coffee aroma (PUTRANTO; CHEN; 2012; RUOSI et al., 2012). The roasting index of coffee grains can be measured by comparison with an end-point color standard. The Agtron Roast Color Classification System (Specialty Coffee Association of America - SCAA) assigned a number for each color according to grain reflectance in which the darkest level is classified as $n^{\circ} 25$ and the lightest as $\mathrm{n}^{\circ} 95$ (ABIC, 2013).

The coloration is directly related to consumer preferences, which varies according to the region, customs and drink preparation. According to the Brazilian standard, roasted beans can be classified between discs $\mathrm{n}^{\circ} 75$ and 45 , which corresponds to the light and moderately dark roasting index, respectively (ABIC, 2013). Within this range, grains lose between 15 and $19 \%$ of mass during the process (FRANÇA et al.; 2009; MOON et al.; 2009; SCHWARTZBERG, 2011).

During the coffee mass loss, it is possible to distinguish drying phase and roasting phase (WANG; LIM, 2013). In the first, water removal and volatile compounds are predominant; while in the second, exothermic reactions releasing mainly organic compounds and carbon dioxide take place (FRANÇA et al.; 2009).

According to França et al. (2009), there is a relationship between mass loss and roasting time. This relationship can have both linear and logarithmic, which depends on the roaster temperature, being linear at $300{ }^{\circ} \mathrm{C}$ and logarithmic at $200{ }^{\circ} \mathrm{C}$. The coffee mass loss modeling in fluidized bed was studied to explain how the chlorogenic acids are degraded in this process (PERRONE et al., 2010).

Increased roasting temperatures have direct effect on total mass loss (FRANÇA et al.; 2009), which enables the establishment of mass loss rates for each roaster temperature. This fact was also observed in fluidized bed roasters (SCHWARTZBERG, 2011).

The Arrhenius model can describe the relationship between mass loss rates and roaster temperatures (WANG; LIM, 2013). This model provides adequate experimental precision on tracking high air temperatures. In addition, it can determine the activation energy $\left(E_{a}\right)$ and the preexponential factor $\left(k_{0}\right)$.

Therefore, the kinetics study allows relating the variation in grain mass and roasting times, which are directly dependent on the temperature and the time throughout this process. Since the horizontal cylinder roaster is widely used in both Brazilian industry and in small farms, we aimed to investigate the relationship between the mass variation rate of the coffee beans and the roaster temperature in getting roasted beans on a commercial level with sensory quality of soft type coffee. 


\section{MATERIAL AND METHODS}

This study was developed in the Analytical Laboratory for Physical, Sensorial and Quality Analyses of Agricultural Goods from the National Training Center in Storage (CENTREINAR), which belongs to the Department of Agricultural Engineering located in the Universidade Federal de Viçosa - UFV (Federal University of Viçosa), in Viçosa, Minas Gerais, Brazil.

Beans of Coffea arabica L., var. Catuaí Vermelho, with size above the sieve 17 and initial water content of $0.1217 \mathrm{~kg} \mathrm{~kg}^{-1}$ were obtained from a coffee processing unit located in Viçosa-MG, Brazil. The grains were subjected to a sensorial analyses based on soft beverage pattern with an overall score between 80 and 85 points.

Coffee processing was performed in a direct combustion gas roaster from the Rod Belcompany with a perforated cylinder into rotary motion at $45 \mathrm{rpm}$, with pre-heating and capacity for $350 \mathrm{~g}$ of raw coffee. During all the process, the gas flaring was kept constant. In addition, it was used the infrared portable thermometer, from the Multi-Temp company, which provided readings between -50 and $500^{\circ} \mathrm{C}$ with a time of response equal to $1 \mathrm{~s}$, resolution of $0.1^{\circ} \mathrm{C}$ and distance of 20 $\mathrm{cm}$ from the target. The roasting temperatures were recorded on the internal wall of the moving cylinder allowing maximum variation of $5^{\circ} \mathrm{C}$, as show Figure 1 . The temperatures used were 380 , 345,325 and $285^{\circ} \mathrm{C}$.

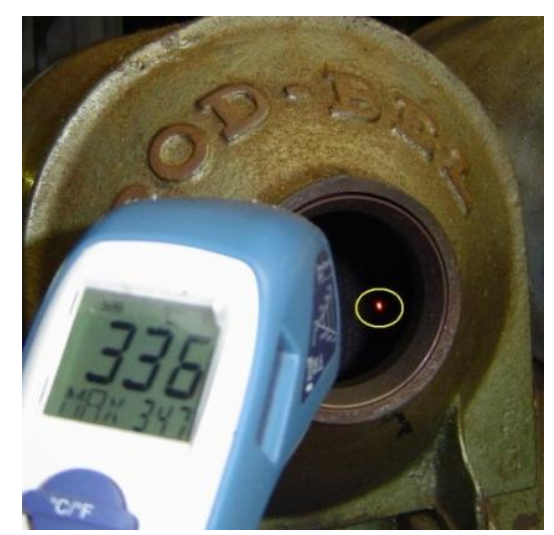

FIGURE 1. Temperature measurement in the roaster cylinder in motion.

Four roasting indexes were set based on grain color and classified as medium light, medium, moderately dark and dark, which were associated to the Agtron Classification, following respectively SCAA\#65, SCAA\#55, SCAA\#45 and SCAA\#35, as shown in Figure 2. After roasting, hot beans were cooled at ambient temperature of $26 \pm 1{ }^{\circ} \mathrm{C}$ to stop exothermic reactions involved whilst roasting process.
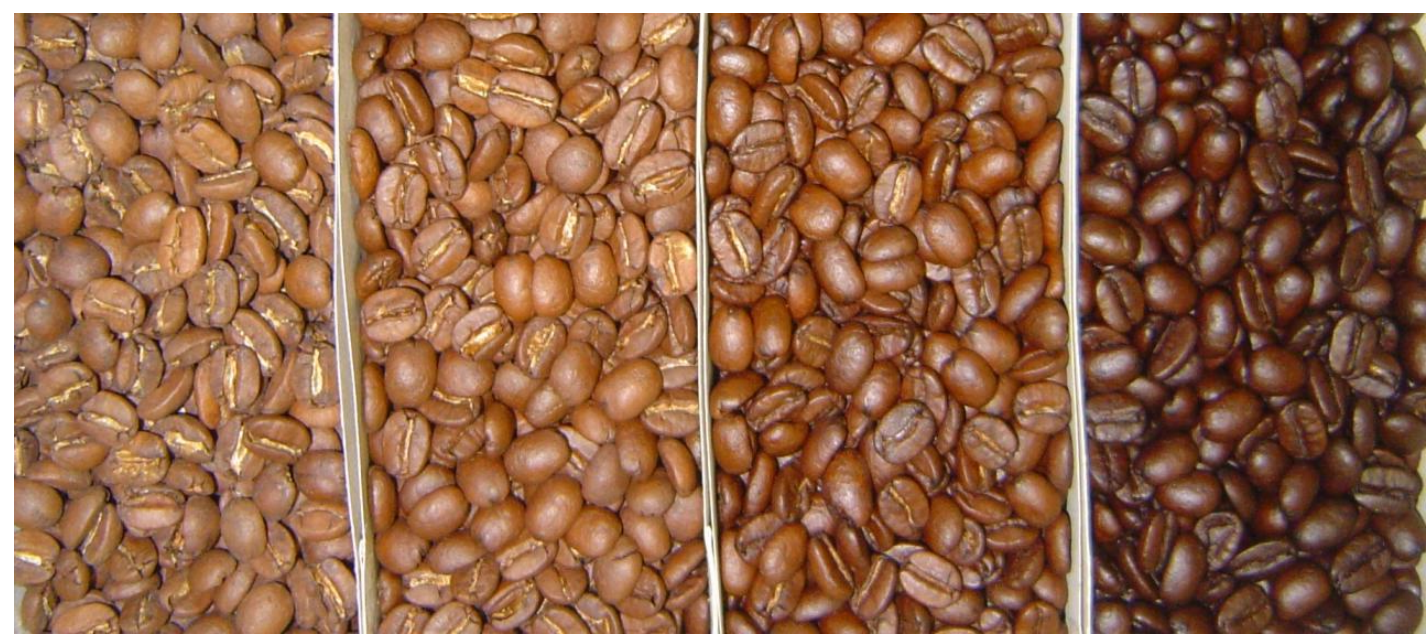

FIGURE 2. Coffee bean color according to the roasting index. 
The final product was weighed using a digital scale with a precision of $0.01 \mathrm{~g}$ to determine initial and final weights in three replications. The mass loss was calculated from the total weight of the grain before and after the roasting according to [eq. (1)].

$$
M=100 \cdot\left(\frac{m_{c}-m_{t}}{m_{c}}\right)
$$

In which,

$M$ - grain mass loss during the roasting, in \%;

$m_{c}$ - raw beans total mass, in $\mathrm{kg}$;

$m_{t}-$ roasted beans total mass, in $\mathrm{kg}$.

The mass loss rate of the grains to achieve a commercial color, at certain temperature, is constant for cylindrical type roaster (VARGAS-ELÍAS, 2011), and can be described by [eq. (2)].

$$
\frac{d M}{d t}=k
$$

In which,

$k$-coffee beans mass lose rate $\min ^{-1}$;

$t$ - time that occurs the process, in min.

The mass loss variation rates are related to roaster temperature according to the Arrhenius model as shows [eq. (3)].

$$
k=k_{0} \cdot \exp \left(\frac{-E_{a}}{R_{g} \cdot T_{a}}\right)
$$

In which,

$k_{0}$ - pre-exponential factor, $\min ^{-1}$;

$E_{a}$ - activation energy, $\mathrm{J}^{\mathrm{mol}^{-1}}$;

$R_{g}$ - gas constant, $8.3145 \mathrm{~J} \mathrm{~mol}^{-1} \mathrm{~K}^{-1}$;

$T_{a}$ - absolute roaster temperature, $\mathrm{K}$. equation:

The kinetics of mass loss in function of the roaster temperature is described by the following

$$
\frac{d M}{d t}=k_{0} \cdot \exp \left(\frac{-E_{a}}{R_{g} \cdot T_{a}}\right)
$$

This experiment was carried out in a split-plot design, in which the four roaster temperatures represented the plots and the four roasting indexes standing for the subplots. Overall, sixteen treatments were conducted with three replications.

\section{RESULTS AND DISCUSSION}

Table 1 shows that the four roasting indexes were obtained regardless roaster temperature. Moreover, significant differences between the roasting indexes were observed when mass loss was above $0.8 \%$. Therefore, the mass loss is directly related to the roasting index. It was also observed in different varieties of arabica (SCHWARTZBERG, 2011) and conilon coffee (BOTELHO, 2012), 
using the same roaster. Even though roaster temperature had no effect on mass loss, process speed range according to the roaster temperature since it had a significant total time reduction.

TABLE 1. Averages of total mass loss (\%) of roasted coffee beans at four commercial roasting indexes.

\begin{tabular}{lccccc}
\hline \multirow{2}{*}{ Roasting Index } & \multicolumn{5}{c}{ Operating temperature of the roaster } \\
\cline { 2 - 6 } & $255^{\circ} \mathrm{C}$ & $285^{\circ} \mathrm{C}$ & $305^{\circ} \mathrm{C}$ & $335^{\circ} \mathrm{C}$ & Average \\
\hline Medium light & $15.97 \mathrm{~d}$ & $15.85 \mathrm{~d}$ & $15.58 \mathrm{~d}$ & $16.01 \mathrm{~d}$ & $15.85 \pm 0.36$ \\
Medium & $17.23 \mathrm{c}$ & $16.67 \mathrm{c}$ & $17.03 \mathrm{c}$ & $17.16 \mathrm{c}$ & $17.02 \pm 0.36$ \\
Moderately dark & $18.85 \mathrm{~b}$ & $18.78 \mathrm{~b}$ & $18.77 \mathrm{~b}$ & $18.57 \mathrm{~b}$ & $18.74 \pm 0.20$ \\
Dark & $21.26 \mathrm{a}$ & $20.48 \mathrm{a}$ & $20.42 \mathrm{a}$ & $20.15 \mathrm{a}$ & $20.58 \pm 0.74$ \\
\hline
\end{tabular}

The averages followed by the same letter in the columns do not differ by Tukey test at $5 \%$ of probability.

Figure 3 shows four kinetics of mass loss for each roaster temperature, properly fitting a linear relationship between the mass loss and the roasting time with $r^{2}$ values varying from 0.953 to 0.983 .

The angular coefficients of the linear relationship represented mass loss rate of the grains set by [eq. (2)], ranging due to roaster temperature. An increase of the initial roster temperature at 95 ${ }^{\circ} \mathrm{C}$ raised the mass variation rate in five times nearly, being from 0.6 to $3.0 \% \mathrm{~min}^{-1}$. In addition, the reduction of processing time from 24 to 9 min, with mass loss equals to $16 \%$, resulted in grains with a light roasting index, besides meeting with the international recommendations about the time.

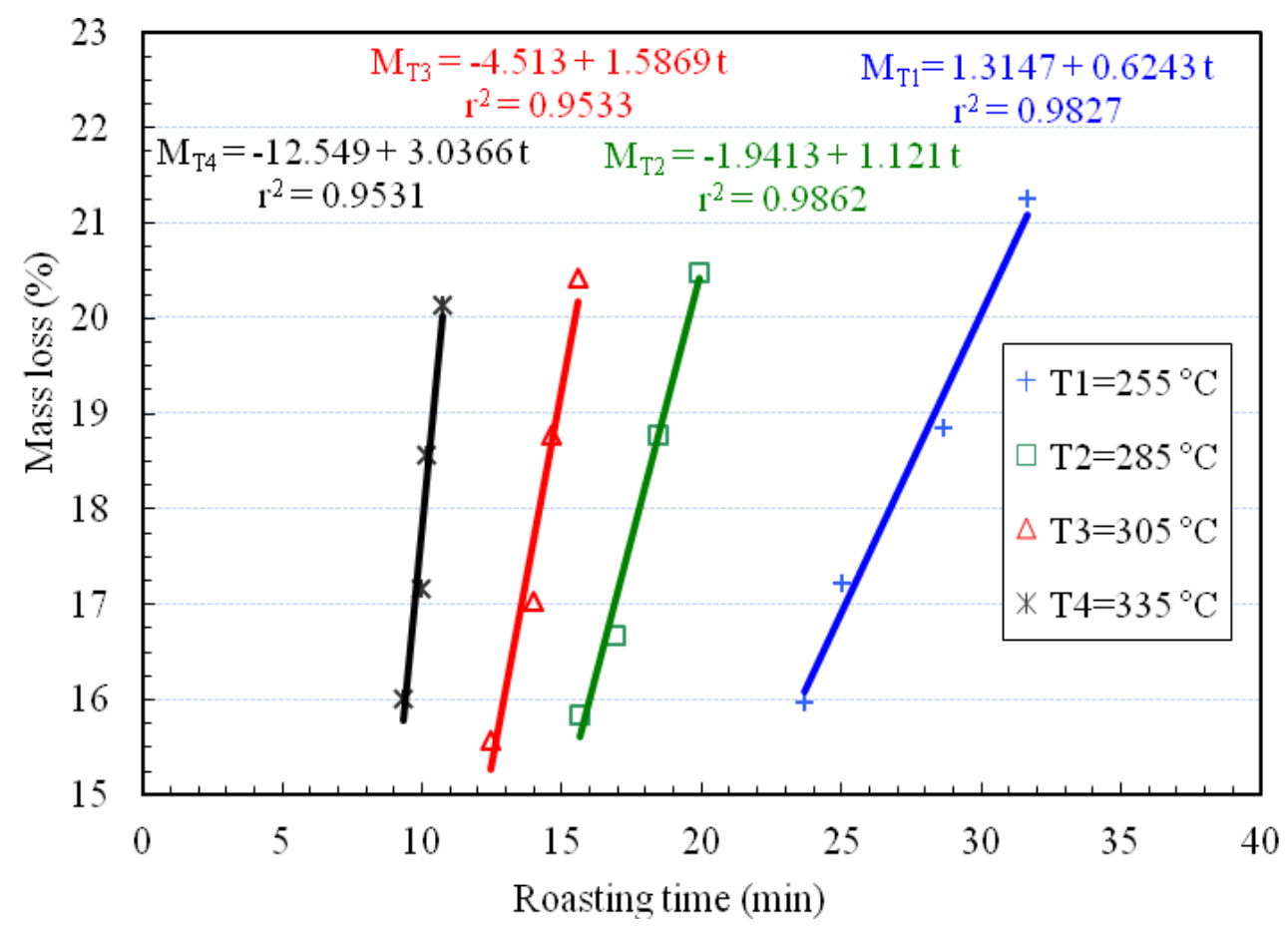

FIGURE 3. Mass loss kinetics of the roaster coffee samples at four temperatures, which resulted in four roasting indexes since medium light until dark.

Table 2 demonstrates that the reduced cylinder temperatures during grain admission were due to heat transfers from roaster wall to the raw grains which were initially at $25{ }^{\circ} \mathrm{C}$, being at least 10 times colder. Therefore, the process had occurred under non-isothermal conditions, changing the initial condition and reaching a balance after $2.5 \mathrm{~min}$ until the end of the process. The grain mass loss rates $(\mathrm{k})$ were associated with the final operating temperature $\left(\mathrm{T}_{\mathrm{f}}\right)$ in Arrenhius model as 
described in [eq. (3)], in which are required the inverse of the absolute temperature $\left(\mathrm{T}_{\mathrm{f}}{ }^{-1}\right)$ and the logarithm of the mass loss rate (ln k).

TABLE 2. The roaster heat parameters before and after placing coffee beans.

\begin{tabular}{|c|c|c|c|c|c|}
\hline \multicolumn{3}{|c|}{ Roaster temperature } & \multirow{2}{*}{$\begin{array}{c}\mathrm{T}_{\mathrm{f}}^{-1} \\
\left(10^{-3} \mathrm{~K}^{-1}\right)\end{array}$} & \multirow{2}{*}{$\begin{array}{c}\mathrm{k} \\
\left(\operatorname{Min}^{-1}\right)\end{array}$} & \multirow{2}{*}{$\begin{array}{c}\ln (\mathrm{k}) \\
\text { Dimensionless }\end{array}$} \\
\hline Initial $\left({ }^{\circ} \mathrm{C}\right)$ & Final $\left({ }^{\circ} \mathrm{C}\right)$ & $\mathrm{T}_{\mathrm{f}}(\mathrm{K})^{\mathrm{a}}$ & & & \\
\hline $380 \pm 6$ & $335 \pm 5$ & 608.15 & 1.6443 & 3.0366 & 1.1107 \\
\hline $345 \pm 3$ & $305 \pm 2$ & 578.15 & 1.7296 & 1.5869 & 0.4618 \\
\hline $325 \pm 5$ & $285 \pm 2$ & 558.15 & 1.7916 & 1.1210 & 0.1142 \\
\hline $285 \pm 3$ & $255 \pm 2$ & 528.15 & 1.8934 & 0.6243 & -0.4711 \\
\hline
\end{tabular}

Through Figure 4, it can be noted that a linear regression of Arrhenius model with $\mathrm{r}^{2}$ above 0.99 , suitably determined $\mathrm{k}_{0}$ and $\mathrm{E}_{\mathrm{a}}$ parameters, by the line and axis intersection $\ln (k)$ and by angular coefficient, respectively. In addition, when roaster operated under non-isothermal conditions, there was an activation energy of 52272.4 $\mathrm{J} \mathrm{mol}^{-1}$ with a pre-exponential factor equals to $89207.3 \mathrm{~min}^{-1}$.

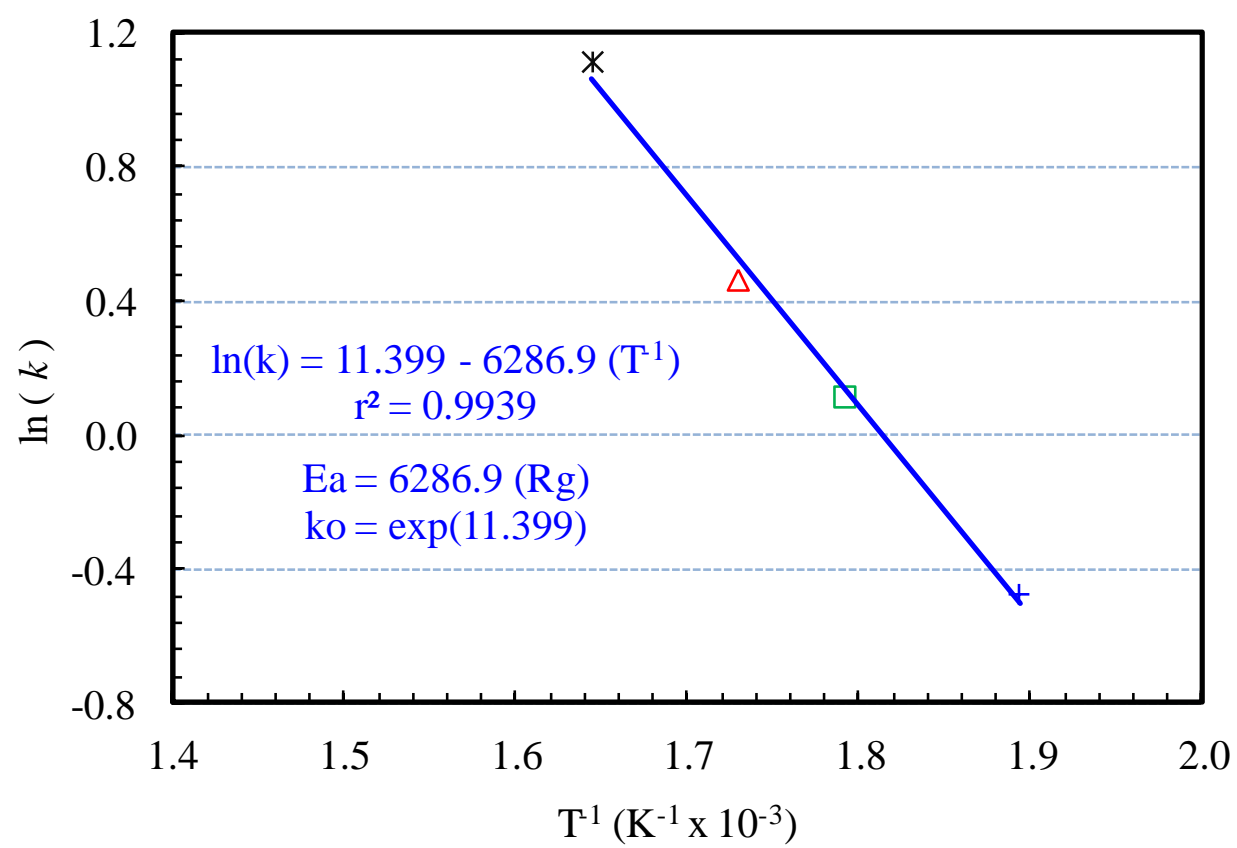

FIGURE 4. Linear adjustment of the roaster temperature inverse and logarithm of the coffee mass loss rate.

On the other hand, the activation energy to start mass loss during coffee roasting $(52.27 \mathrm{~kJ}$ $\mathrm{mol}^{-1}$ ) was higher than findings of other researches, with physical changes happening during the drying process. It indicates that during the roasting was required more energy to start physical and chemical transformations. In Macassar beans, the beginning of diffusive process requires an activation energy of $26.9 \mathrm{~kJ} \mathrm{~mol}^{-1}$ (SILVA et al., 2008); for red variety beans, it was $15.7 \mathrm{~kJ} \mathrm{~mol}^{-1}$ associated with volume contraction (CORRÊA et al., 2011). Furthermore, during the drying of cherry type coffee beans, this activation energy may vary between arabica and conilon varieties, being of 38.39 (OLIVEIRA et al., 2010) and $38.02 \mathrm{~kJ} \mathrm{~mol}^{-1}$ (BOTELHO, 2012), respectively.

Wang and Lim (2013) studied the drying and roasting stages and found an activation energy of 53.49 during the first and of $184.15 \mathrm{~kJ} \mathrm{~mol}^{-1}$ during the second. Therefore, the coffee roasting demands more energy than the bean drying process whether using a fluidized bed roaster and hot air from 220 to $250{ }^{\circ} \mathrm{C}$. 
Under processes of chemical changes like arabica coffee roasting with heat transfers through hot air convection between 170 and $200^{\circ} \mathrm{C}$, an activation energy for chlorogenic acid degradation should be of $44.4 \mathrm{~kJ} \mathrm{~mol}^{-1}$ (PERRONE et al., 2010). Another research has shown that after the roasting process at temperatures between 180 and $240{ }^{\circ} \mathrm{C}$, previously contaminated grains with ochratoxin A had infection levels reduced from 8 to $98 \%$, using an activation energy of $49.2 \mathrm{~kJ} \mathrm{~mol}^{-}$ ${ }^{1}$ (FERRAZ et al., 2010). The value determined in this study was higher than the above examples, indicating that the mass loss mechanis $m$ in the roasting indexes studied comes after degradation of both chlorogenic acids and ochratoxin A.

Based on the energy released by grains during the exothermic reactions, the activation energy was of $45.73 \mathrm{~kJ} \mathrm{~mol}^{-1}$. This value was used in computer simulation (ALONSO-TORRES et al., 2013) as well as in numerical solution (BOTTAZZI et al., 2012) of the coffee roasting modeling, with an air temperature between 200 and $250^{\circ} \mathrm{C}$. The activation energy to start the exothermic reactions was lower than that required for roasted bean mass loss, indicating that the exothermic mechanism begins before reaching the roasting indexes studied (FRANÇA et al., 2009).

Figure 5 displays the comparison between the calculated mass loss rates and the experimentally determined ones with a linear adjustment of 0.993 .

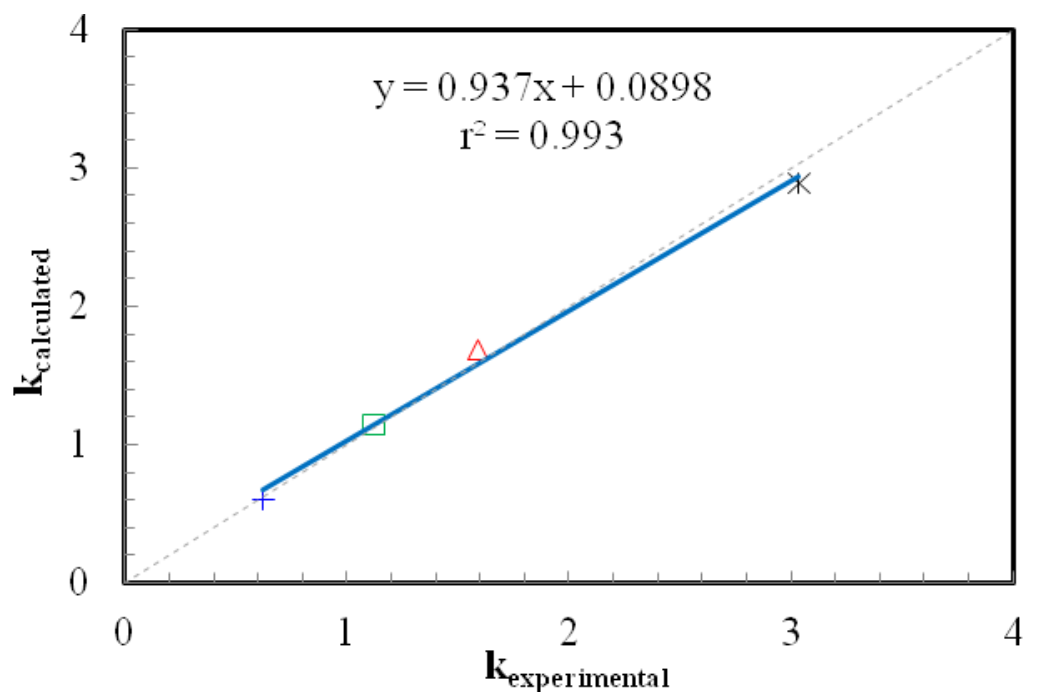

FIGURE 5. Linear adjustment between the mass loss rates determined experimentally and calculated ones.

Thus, we can set the mass loss kinetics in coffee beans through the [eq. (5)], which is based on the temperature of the roaster walls during coffee processing:

$$
\frac{d M}{d t}=89207.3 \cdot \exp \left[\frac{-52272.4}{8.3145\left(T_{f}+273.15\right)}\right]
$$

\section{CONCLUSIONS}

1. The grain-roasting index is directly correlated to respective grain mass loss. 2 . The temperature during coffee processing determined the kinetics of mass loss in bean roasting. 3. The increase in roaster temperature reduced both total time and the times between each roasting level. 4 . The linear model of mass loss kinetics properly represented the operating conditions of the cylindrical roaster. 5. The Arrhenius model adequately depicted the roasting coffee temperatures under the studied conditions. 


\section{ACKNOWLEDGMENTS}

The authors want to thank the Universidad de Costa Rica, CNPq, CAPES and FAPEMIG for the financial support during the research.

\section{REFERENCES}

ABIC - ASSOCIAÇÃO BRASILEIRA DE INDÚSTRIA DO CAFÉ. Norma de qualidade recomendável e boas práticas de fabricação de cafés torrados em grão e cafés torrados e moídos. - Revisão 26 Agosto 2013. Disponível em:

<http://www.abic.com.br/publique/media/Norma\%20de\%20qualidade.pdf $>$. Acesso em: 3 jan. 2014.

ALONSO-TORRES, B.; HERNÁNDEZ-PÉREZ, J.A.; SIERRA-ESPINOZA, F.; SCHENKER, S.; YERETZIAN, C. Modeling and validation of heat and mass transfer in individual coffee beans during coffee roasting process using Computational Fluids Dynamics (CFD). CHIMIA, Zurick, v. 67, n. 4, p. 291-294, 2013.

BASILE, M.; KIKIC, I. A lumped specific heat capacity approach for predicting the non-stationary thermal profile of coffee during roasting. Chemical and Bioche mical Engineering Qarterly, Chuarterly, v. 3, n 2, p. 167-177. 2009.

BONNLÄNDER, B.; EGGERS, R.; ENGELHARDT, U.H.; MAIER, H.G. Roasting. In: ILLY, A.; VIANI, R (ed.). Es presso coffee: the science of quality. Elsevier Academic Press. Second edition. 398 p. 2005.

BOTELHO, F.M. Cinética de secagem, propriedades físicas e higroscópicas dos frutos e caracterização do processo de torrefação dos grãos de Coffea canephora. 2012. 129 f. Tese (Doutorado em Engenharia Agrícola) - Universidade Federal de Viçosa, Viçosa, 2012.

BOTTAZZI, D.; FARINA, S.; MILANI, M.; MONTORSI, L. A numerical approach for the analysis of coffee roasting process. Journal of Food Engineering, New York, v. 112, p. 243-252, 2012.

CORREAA, P.C.; RESENDE, O.; GARIN, S.A.; JAREN, C.; OLIVEIRA, G.H.H. Mathematical models to describe the volumetric shrinkage rate of red beans during drying. Engenharia Agrícola, Jaboticabal, v.31, n.4, p. 716-726, jul./ago. 2011.

FABBRI, A.; CEVOLI, C.; ALESSANDRINI, L.; ROMANI, S. Numerical modeling of heat and mass transfer during roasting process. Journal of Food Engineering, New York, v. 105, p. 264269, 2011.

FERRAZ, M.B.M.; FARAH, A.; IAMANAKA, B.T.; PERRONE, D.; COPETTI, M.V.; MARQUES, V.X.; VITALI, A.A. TANIWAKI, M.H. Kinetics of ochratoxin A destruction during coffee roasting. Food Control. Guildford, v. 21, p. 872-877. 2010

FRANÇA, A.S.; OLIVEIRA, L.S.; OLIVEIRA, R.C.S.; AGRESTI, P.C.M.; AUGUSTI, R. A preliminary evaluation of the effect of processing temperature of coffee roasting degree assessment. Journal of Food Engineering, Essex, v. 92, p. 345-352, 2009.

MOON, J.K.; YOO, H.S.; SHIBAMOTO, T. Role of roasting conditions in the level of chlorogenic acid content in coffee beans: Correlation with coffee acidity. Journal of Agricultural and Food Che mistry, Washington, v. 57, p. 5365-5369, 2009.

OIC - Organização Internacional do Café (2013). Reexportações de café da Alemanha. ICC 1104. Londres. Março 2013. Disponível em: <

http ://ico.heritage4.com/?section=What_We_Do?section=Documents >. Acesso em: 5 de jan. 2014. 
OLIVEIRA, G.H.H.; CORRÊA, P.C.; BOTELHO, F.M.; VARGAS-ELÍAS, G.A.; DINIZ, M.D.M.S. Analysis of thermodynamic properties of coffee berries during drying. In: XVII WORLD CONGRESS OF THE INTERNATIONAL COMMISSION OF AGRICULTURAL AND BIOSYSTEMS ENGINEERING, 17., 2010, Chébec. Proceedings...

PERRONE, D.; DONANGELO, R.; DONANGELO, C.M.; FARAH, A. Modeling weight loss and cholorogenic acids content in coffee during roasting. Journal of Agricultural and Food Che mistry. Washington, v 58, p 12238-12243. 2010.

PUTRANTO, A.; CHEN, X. D. Roasting of barley and coffee modeled using the lumped-reaction engineering approach (L-REA). Drying Technology. New York, v. 30, p. 475-483, 2012.

RUOSI, M.R.; CORDERO, C.; CAGLIERO, C.; RUBIOLO, P; BICCHI, C.; SGORBINI, B.; LIBERTO, E. A further tool to monitor the coffee roasting process: Aroma composition and chemical indices. Journal of Agricultural and Food Che mistry, Washington, v. 60, p. 1128311291. 2012.

SCHWARTZBERG, H. Batch coffee roasting; roasting energy use; reducing that use. In: INTERNATIONAL CONGRESS ON ENGINEERING AND FOOD, 2011, Athens.

Proceedings... Disponível em www.icefl1.org/content/papers/fpd/FPD260.pdf

SILVA, W.P.; MATA, M.E.R.M.; SILVA, C.D.S.P.; GUEDES, M.A.; LIMA, A.G.B. Determinação da difusividade e da energia de ativação para feijão macassar (Vigna unguiculata), variedade sempre-verde, com base no comportamento na secagem. Engenharia Agrícola, Jaboticabal, v.28, p. 325-333, abr./jun. 2008.

VARGAS-ELÍAS, G. A. Avaliação das propriedades físicas e qualidade do café em diferentes condições de torrefação. 2011. 114 f. Dissertação (Mestrado em Engenharia Agrícola). Universidade Federal de Viçosa, Viçosa. 2011.

WANG, X.; LIM, L.T. A kinetics and modeling study of coffee roasting under isothermal conditions. Food Bioprocess Technology, New York. In press. doi: 10.1007/s11947-013-1159-8). 2013 Disponível em: < http://link. springer.com/article/10.1007/s11947-013-1159-8>. Acesso em: 25 nov. 2013. 